Ethiopian Journal of Environmental Studies \& Management 7 Suppl.: 709 - 719, 2014.

ISSN:1998-0507

doi: http://dx.doi.org/10.4314/ejesm.v7i1.2S

Submitted: April 03, 2014

Accepted: October 30, 2014

\title{
EVALUATING YIELD PERFORMANCE OF COWPEA VARIETIES UNDER SOLE AND INTERCROPPING WITH SORGHUM AT BAUCHI, NIGERIA
}

\author{
*IBRAHIM, H.A., ${ }^{1}$ SINGH, L. ${ }^{2}$ AND BABAJI, G.A. ${ }^{3}$ \\ ${ }^{1}$ Department of Plant Science, College of Agriculture and Veterinary Sciences, Ambo \\ University, P,O.Box 19, Ambo, Ethiopia \\ ${ }^{2}$ Department of Crop Production, Faculty of Agriculture, Modibbo Adama University of Science \\ and Technology, Yola, Adamawa, Nigeria \\ ${ }^{3}$ Department of Soil Science, Faculty of Agriculture, Abubakar Tafawa Balewa University, \\ Bauchi, Nigeria
}

\begin{abstract}
Field experiments were conducted during the rainy seasons of 1997 and 1998 at the Abubakar Tafawa Balewa University Research Farm, Bauchi $\left(10^{\circ} 20^{\prime}\right.$ and $\left.9^{\circ} 48^{\prime} E\right)$ to evaluate the yield performance of some Cowpea varieties under Sole and Intercropping with Sorghum at Bauchi, Nigeria. The treatments consist of Sole Cowpea, Cowpea + Sorghum and Sole Sorghum which makes up the main treatment and ten Cowpea varieties (IT89KD-391, IT93K-452-1, IT90K-277-2, IT86D-719, IT89KD-349, IT93K-734, IT93K-273-2-1, IT90K-372-1-2, and Local yar dunga (L)) combined factorially in a split plot design with three replications. Results revealed that Cowpea Plant height, Days to fifty percent flowering, Leaf area and Leaf area indices were not significantly affected by intercropping in 1997 and 1998. The mean number of pod/plant, pod weight and seed yield of the cowpea varieties showed a significant difference in Sorghum intercrop. Sorghum Plant height, Leaf area and Leaf area indices were significantly affected by intercropping in 1997 and 1998 cropping seasons. Similarly Sorghum stover and grain yield were significantly affected by intercropping. Land equivalent ratio greater than 1.00 was recorded in the two years of the investigation. For intercropping purpose, it is therefore suggested that varieties IT9OK-372-1-2, IT90K-277-2, IT88D-867-11, IT89KD-391 and IT86D-719 are more suitable for high yields in Bauchi.
\end{abstract}

Key Words: Cowpea, Sorghum, Yield, Sole, Intercropping, Bauchi

\section{Introduction}

In spite of the high productivity of crops when planted sole and the ease of efficient utilization of inputs for improved agronomic practices, intercropping system continued to dominate the cropping pattern of peasant farmers in Nigeria (Singh, 1981). Some of the advantages attributed to mix as compared to sole cropping include risk aversion, extensive and intensive use of resources (land

\footnotetext{
*Corresponding Author: Ibrahim, H.A.

Email: haiayi@yahoo.com and labor), greater return per unit land area, reduction of pest and diseases and the possible improvement of soil fertility. Intercropping legumes with cereals especially sorghum and maize is a common practice in the northern guinea savanna ecological zone of Nigeria.

In the West Africa savanna, the intensification of agricultural systems has resulted in declining nutrient availability, soil 
acidification, compaction and build-up of pest problems seriously affecting soil productivity and affecting soil fertility and the overall yield of crops (Webber et al., 1996). Recently there has been a renewed effort to address these problems through the introduction of legumes into the production systems (COMBS, 1993). In terms of land use growing crops in mixed stand is regarded as more productive than growing them separately. One of the justifications is the belief that some of the nitrogen fixed by the legume would be transferred to the associated crops. It has been reported that the inclusion of legumes in grass pastures often increase grass and protein yield as a result of the nitrogen fixed by the legume to the associated crop especially when they grow together for a long period (Goodman and Collinson, 1986). The yield advantages of legume- cereal intercropping system over sole have been reported (Pal et al., 1993). However results demonstrated varietal differences in the cowpea response to method of planting. Elemo and Olufajo (1991) observed that maize grain yield was not affected by the intercropped cowpea, but cowpea grain yield was reduced by $19 \%$ in the sole crop.

Planting pattern has been shown to differentially affect intercrop yield. Agboola and Fayemi (1971) found that there was no significant difference between alternating pure stand rows versus mixed stand rows, and that maize intercrop yielded significantly more when planted in alternate rows than when planted in the same row with cowpea.

In the guinea savanna zone of Nigeria, it has been found that, the highest maize yield from a mixture was attained when two stand of maize alternate with one stand of cowpea, and highest yield of cowpea were attained by alternating two rows of cowpea with one row of maize. Blade and Terao (1993) reported that an improved erect early variety, IT82D-
716 produced higher grain yield in high density Monocropping, but yield was low when intercropped with cereal. The local spreading type is more adapted to intercropping, although the grain yield was low relative to IT86D-716. Wanki et al. (1982) reported an increased yield of maize and cowpea when intercropped than when grown as sole crops. Ofori and Stern (1982) reported an increased dry matter production, yield and leaf area index in maize-pigeon pea intercropping system as compared to sole crops. While intercropping maize with either beans or cowpeas decreased total yield of grain (cereal and legume) per hectare, intercropping sorghum with pigeon peas increased total grain yield per hectare (Enyi, 1973).

Several different concepts have been developed to assess yield of intercrops. As yields of different crops cannot be compared directly with each other, but it is generally accepted that more than one yield analysis should be applied to intercropped data. Wiley (1979) proposed the land equivalent ratio (LER), which is the relative land required as sole crop to produce the same yield as intercropping, Land equivalent ratio provides a standardized basis for crops to be added to form "combined" yields.

In intercrop systems, the major soil nutrient for which component crops compete when in limited supply are nitrogen, phosphorus and potassium. Savanna soils are known to be low in organic matter and since nitrogen has been known to be a most important limiting factor for cereal production, frequent addition of these nutrients is required for high yield maintenance. In the guinea savanna yields of crops under intercropping conditions is low due to poor standard of husbandry and factors related to fertilizer use.

The increasing high cost of chemical fertilizers and the scarcity of the commodity 
call for a relatively cheaper alternative to fertilizer application, so as to increase crop production while at the same time improving the fertility of the soil.

In view of the above, this research was undertaken to study the yield performance of some cowpea varieties and sorghum under sole and intercropping.

\section{Materials and Method Experimental site}

Field experiment was conducted during the wet season (May - October) of 1997 and 1998 at the Abubakar Tafawa Balewa University Research Farm, Bauchi (located at approximately $10^{\circ} 22^{\prime} \mathrm{N}$ and $9^{\circ} 47^{\prime} \mathrm{E}$ ) with an elevation of $609.52 \mathrm{M}$ above sea level in the Northern Guinea Savanna Ecological Zone of Nigeria.

The soils of Bauchi state are mostly sandy loam, slight to moderately acid in reaction, therefore the soil can be described as fragile (Nnadi, 1980).

\section{Treatment and Experimental Design}

The treatment consisted of three planting patterns (Sole cowpea, Cowpea + Sorghum, and Sole sorghum) which make up the main treatments and ten cowpea varieties (IT89KD-391, IT93K-452-1, IT90K-2772,IT86D-719, IT89KD-349, IT88D-86711,IT93K-734, IT93K-273-2-1, IT90K-3701-1 and Yar dunga (local variety) as control, constituting the sub-treatments combined factorially in a split plot design in three replications and randomly allocated to plots.

\section{Agronomic Practices}

\section{Planting and Planting Materials}

The land was cleared and harrowed twice to obtain a fine tilth. The field was then marked out into sixty plots of $15 \mathrm{~m}^{2}$ and $24 \mathrm{~m}^{2}$ for sole and intercropped plots respectively. A discard of $2 \mathrm{~m}$ was allowed in between replications and $1 \mathrm{~m}$ between plots.

Planting was carried out for the first and second cropping season on the $22^{\text {nd }}$ June and $6^{\text {th }}$ June 1997 and 1998 wet season respectively. The cowpea varieties were the improved type, high yielding and semiupright, while sorghum variety KSV-8 was used. The cowpea and sorghum were all sown simultaneously using a plant spacing of $75 \mathrm{~cm} \times 25 \mathrm{~cm}$ row to row and plant to plant for cowpea and $75 \mathrm{~cm} \times 30 \mathrm{~cm}$ for sorghum. In the intercropped plot two rows of sorghum was planted with four rows of cowpea.

Single superphosphate fertilizer was applied preplanting at the rate of $60 \mathrm{kgP}_{2} \mathrm{O}_{5} /$ ha to cowpea, while sorghum received $60 \mathrm{kgN} / \mathrm{ha}$ NPK (15:5:15) split applied and the second application was at 6 weeks after germination. The fertilizer was side dressed and covered with soil to minimize volatilization losses.

Weed control was done manually at 3 and 6 weeks after planting. No pre-flowering insect pest was noticed up to about 6 weeks after germination on the cowpea varieties. During the flowering and podding stage, insect and disease infestation was noticed. Sherpa plus EC was used at the rate of one liter per hectare to control the pest and disease. Two spraying of cowpea was carried out using a CP3 knapsack sprayer.

Harvesting of sorghum was done at physiological maturity. Grain yield was standardized by further sun drying for two weeks after harvesting from the field.

Harvesting of the cowpea crop was started at the $10^{\text {th }}$ week after planting from a net plot of $7.5 \mathrm{~m}^{2}$ for yield determination.

\section{Observation and Data Collection}

All observations on growth and yield components were made on five plants randomly sampled from two outer rows. Data collected on the growth of the crop included; plant height, leaf area and leaf area index, days to $50 \%$ flowering, number of pods/plant, number of seeds/pod, seed weight, threshing percentage and weight of 1000 seed for cowpea were recorded. In the 
case of sorghum, plant height, leaf area and leaf area index. Head weight, threshing percentage, 1000 seed weight, stover yield, and grain yield were also recorded using appropriate methods and procedure. All observation on sorghum was at 10 weeks after germination. Plant height was measured from the base of the plant to the tip of the shoot with a standard meter rule. The leave area was measured by taken the average of 5 plants/plot. The length (L) of all the leaves/plant and the maximum width (W) multiplied by a leaf area factor 0.75 (Pal, 1985). The leaf area index was calculated by dividing the leaf area by the area covered by the plant.

The cowpea leaf area was determined by stacking the leaf laminae of the sample plants on the table and a cork borer of known area was driven through them to cut out discs. The complete disc where counted and weighed both when fresh and after drying. The remaining parts after cutting of discs where combined as per the discs. The weights obtained were used to determine the leaf area as described by Watson (1958).

$\mathrm{A}=(\mathrm{a} * \mathrm{n}) / \mathrm{w} * \mathrm{~W}$

Where:

$\mathrm{A}=$ Total leaf area/plant $\left(\mathrm{cm}^{2}\right) ; \mathrm{a}=$ area of individual discs $\left(\mathrm{cm}^{2}\right) ; \mathrm{n}=$ number of discs taken; $\mathrm{w}=$ weight of fresh $\mathrm{n} \operatorname{discs}(\mathrm{g})$ and $\mathrm{W}$ $=$ Total fresh weight of leaves/plant $(\mathrm{g})$.

The land equivalent ratio was calculated as described by Wiley (1979).

$$
\mathrm{LER}_{\text {cowpea-sorghum }}=\frac{\text { cowpea yield (mixture) }}{\text { sole cowpea yield }}+\frac{\text { sorghum yield (mixture) }}{\text { sole sorghum yield }}
$$

\section{Analysis of Data}

The MSTAT statistical package was used to analyze the data. Where the treatment effects were significant, the Duncan Multiple Range Test (DMRT) was used to compare treatment means.

\section{Results and Discussion}

Statistical analysis of the data on sorghum plant height in 1997 and 1998 indicated that sorghum was significantly affected $(\mathrm{p} \leq 0.05)$ by intercropping with cowpea varieties. Intercropping sorghum with varieties IT93K-452-1, IT90K-277-2,
IT89KD-349, IT93-734 and IT88D-867-11 leads to a significant reduction in sorghum plant height (Table 1). This investigation does not corroborates the finding of Desir and Pinchinat (1976), who reported that there was no significant difference between mixed or sole crops in terms of plant height. Sorghum leaf area and leaf area index were significantly affected ( $\mathrm{p} \leq 0.05)$ by intercropping with cowpea varieties. The highest leaf area and leaf area index were recorded with varieties IT90K-277-2, IT89KD-391, IT90K-372-1-2, and IT93K452-1. 
Table 1: Effect of intercropping cowpea varieties on the growth parameters of sorghum in a mixture at Bauchi in 1997 and 1998

\begin{tabular}{|c|c|c|c|c|c|c|c|c|c|}
\hline \multirow[t]{2}{*}{ Treatment } & \multicolumn{4}{|c|}{1997} & \multicolumn{5}{|c|}{1998} \\
\hline & $\begin{array}{l}\text { Plant } \\
\text { height }(\mathrm{cm})\end{array}$ & $\begin{array}{l}\text { Leaf Area } \\
\left(\mathrm{cm}^{2}\right)\end{array}$ & $\begin{array}{l}\text { Leaf } \\
\text { Index }\end{array}$ & Area & $\begin{array}{l}\text { Plant } \\
\text { height }(\mathrm{cm})\end{array}$ & $\begin{array}{l}\text { Leaf } \\
\left(\mathrm{cm}^{2}\right)\end{array}$ & Area & $\begin{array}{l}\text { Leaf } \\
\text { Index }\end{array}$ & Area \\
\hline Sole & 219.7 & 1210.0 & 3.2 & & 208.3 & 1537.5 & & 4.1 & \\
\hline IT89KD-391 & $209.2^{\mathrm{b}}$ & $1231.1^{\mathrm{b}}$ & $3.3^{\mathrm{c}}$ & & $118.3^{\mathrm{a}}$ & $1050.0^{\mathrm{b}}$ & & $2.8^{\mathrm{b}}$ & \\
\hline IT93K-452-1 & $187.8^{\mathrm{a}}$ & $980.5^{\mathrm{b}}$ & $2.6^{\mathrm{ab}}$ & & $181.7^{\mathrm{b}}$ & $975^{\mathrm{b}}$ & & $2.6^{\mathrm{b}}$ & \\
\hline IT90K-277-2 & $193.3^{\mathrm{a}}$ & $1080.6^{\mathrm{b}}$ & $2.9^{\mathrm{b}}$ & & $165.3^{\mathrm{b}}$ & $900.0^{\mathrm{ab}}$ & & $2.4^{\mathrm{b}}$ & \\
\hline IT86D-719 & $209.1^{\mathrm{b}}$ & $788.1 \mathrm{a}$ & $2.1^{\mathrm{a}}$ & & $203.3^{\mathrm{b}}$ & $789.5^{\mathrm{a}}$ & & $2.1^{\mathrm{a}}$ & \\
\hline IT89KD-349 & $194.5 \mathrm{a}$ & $880.0 \mathrm{a}$ & $2.3^{\mathrm{a}}$ & & $198.3^{b}$ & $787.3^{\mathrm{a}}$ & & $2.1^{\mathrm{a}}$ & \\
\hline IT88D-867-11 & $192.3 \mathrm{a}$ & $825.0^{\mathrm{a}}$ & $2.2^{\mathrm{a}}$ & & $150.0^{\mathrm{a}}$ & $712.5^{\mathrm{a}}$ & & $1.9^{\mathrm{a}}$ & \\
\hline IT93-734 & $195.7 \mathrm{a}$ & $690.0^{\mathrm{a}}$ & $1.8^{\mathrm{a}}$ & & $141.7^{\mathrm{a}}$ & $825.0^{\mathrm{a}}$ & & $2.2^{\mathrm{a}}$ & \\
\hline IT93K-273-2-1 & $204.3^{\mathrm{b}}$ & $779.5^{\mathrm{a}}$ & $2.1^{\mathrm{a}}$ & & $211.7^{\mathrm{b}}$ & $750.0^{\mathrm{a}}$ & & $2.0^{\mathrm{a}}$ & \\
\hline IT90K-372-1-2 & $203.4^{\mathrm{b}}$ & $1112.3^{\mathrm{b}}$ & $3.0^{\mathrm{b}}$ & & $205.0^{\mathrm{b}}$ & $862.5^{\mathrm{b}}$ & & $2.3^{\mathrm{b}}$ & \\
\hline Yar Dunga (L) & $215.9^{\mathrm{b}}$ & $890.9^{\mathrm{a}}$ & $2.4^{\mathrm{a}}$ & & $168.1^{\mathrm{a}}$ & $716.4^{\mathrm{a}}$ & & $1.9^{\mathrm{a}}$ & \\
\hline SE & 44 & 108.4 & 0.45 & & 7 & 4 & & 0.18 & \\
\hline
\end{tabular}

Means followed by the same letters are not significantly different at $5 \%$ level of significance, according to the Duncan Multiple Range Test (DMRT)

On cowpea growth parameters, in 1997 there was no significant difference on sole cowpea plant height and days to $50 \%$ flowering (Table 2). The leaf area and leaf area index of the cowpea varieties were also not significant. Generally there was no significant varietal intercropping effect on all the growth parameters observed for cowpea. This result is in agreement with the finding of Singh (1981). Although non-significant, cowpea variety IT86D719 and IT93K-273-2-1 recorded a higher plant height, leaf area and leaf area index when intercropped with sorghum than when planted sole (Table 2). Intercropping cowpea variety with sorghum generally reduced the cowpea plant height and leaf area. The local variety produced the tallest cowpea plants. This agrees with the finding of Ofori and Stern (1987) who reported similar reduction in dry matter production, leaf area and leaf area index under intercropping system.

Table 2: Effect of intercropping cowpea varieties with sorghum on cowpea growth parameters at Bauchi in 1997

\begin{tabular}{|c|c|c|c|c|c|c|c|c|}
\hline \multirow[b]{3}{*}{ Treatment } & \multicolumn{8}{|c|}{1997} \\
\hline & \multicolumn{4}{|c|}{ Intercropped } & \multicolumn{4}{|c|}{ Sole } \\
\hline & $\begin{array}{l}\text { Plant } \\
\text { height } \\
(\mathrm{cm})\end{array}$ & DFF & $\begin{array}{l}\text { Leaf } \\
\text { Area } \\
\left(\mathrm{cm}^{2}\right)\end{array}$ & $\begin{array}{l}\text { Leaf } \\
\text { Area } \\
\text { Index }\end{array}$ & $\begin{array}{l}\text { Plant } \\
\text { height }(\mathrm{cm})\end{array}$ & DFF & $\begin{array}{l}\text { Leaf } \\
\text { Area } \\
\left(\mathrm{cm}^{2}\right)\end{array}$ & $\begin{array}{ll}\text { Leaf } & \text { Area } \\
\text { Index } & \end{array}$ \\
\hline IT89KD-391 & 49.6 & 49 & 18.8 & 0.25 & 55.9 & 48 & 20.8 & 0.28 \\
\hline IT93K-452-1 & 51.3 & 46 & 21.6 & 0.29 & 57.2 & 45 & 19.4 & 0.26 \\
\hline IT90K-277-2 & 33.4 & 46 & 20.3 & 0.27 & 56.7 & 47 & 20.5 & 0.27 \\
\hline IT86D-719 & 64.9 & 44 & 23.7 & 0.32 & 55.8 & 44 & 21.5 & 0.29 \\
\hline IT89KD-349 & 50.5 & 45 & 20.8 & 0.28 & 59.1 & 46 & 22.1 & 0.29 \\
\hline IT88D-867-11 & 55.9 & 46 & 22.7 & 0.30 & 60.0 & 45 & 24.1 & 0.32 \\
\hline IT93-734 & 62.0 & 42 & 19.3 & 0.26 & 61.2 & 44 & 23.3 & 0.31 \\
\hline IT93K-273-2-1 & 59.0 & 43 & 21.7 & 0.29 & 57.8 & 43 & 20.3 & 0.27 \\
\hline IT90K-372-1-2 & 49.0 & 43 & 20.6 & 0.27 & 59.8 & 43 & 21.7 & 0.29 \\
\hline Yar Dunga (L) & 82.7 & 62 & 24.6 & 0.33 & 62.3 & 66 & 24.5 & 0.33 \\
\hline Significance level (0.05) & NS & NS & NS & NS & NS & NS & NS & NS \\
\hline SE & 18.6 & 1.83 & 0.59 & 0.0081 & 0.72 & 2.16 & 0.54 & 0.0072 \\
\hline
\end{tabular}

NS - Not significant; DFF - Days to $50 \%$ flowering 
In 1998, there was no significant difference in both sole and intercropped cowpea varieties on plant height, days to fifty percent flowering, leave area and leave area index (Table 3). Sole cowpea recorded higher values in all measured growth parameters. However highest plant height, leaf area and leaf area index was recorded in the intercropped with Yar Dunga (L), IT90K-372-1-2, IT86D-719, IT89KD-391, and IT93K-273-2-1 respectively.

Table 3: Effect of intercropping cowpea varieties with sorghum on cowpea growth parameters at Bauchi 1998

\begin{tabular}{|c|c|c|c|c|c|c|c|c|}
\hline \multirow[b]{3}{*}{ Treatment } & \multicolumn{8}{|c|}{1998} \\
\hline & \multicolumn{4}{|c|}{ Intercropped } & \multicolumn{4}{|c|}{ Sole } \\
\hline & $\begin{array}{l}\text { Plant } \\
\text { height }(\mathrm{cm})\end{array}$ & DFF & $\begin{array}{l}\text { Leaf } \\
\text { Area } \\
\left(\mathrm{cm}^{2}\right)\end{array}$ & $\begin{array}{l}\text { Leaf } \\
\text { Area } \\
\text { Index }\end{array}$ & $\begin{array}{l}\text { Plant } \\
\text { height }(\mathrm{cm})\end{array}$ & DFF & $\begin{array}{l}\text { Leaf } \\
\text { Area } \\
\left(\mathrm{cm}^{2}\right)\end{array}$ & $\begin{array}{l}\text { Leaf Area } \\
\text { Index }\end{array}$ \\
\hline IT89KD-391 & 69.6 & 50 & 30.2 & 0.4 & 65.9 & 49 & 31.3 & 0.42 \\
\hline IT93K-452-1 & 61.3 & 46 & 29.9 & 0.38 & 69.6 & 47 & 29.9 & 0.40 \\
\hline IT90K-277-2 & 63.4 & 45 & 28.3 & 0.38 & 70.2 & 45 & 30.2 & 0.40 \\
\hline IT86D-719 & 74.9 & 44 & 28.9 & 0.38 & 76.1 & 43 & 28.9 & 0.38 \\
\hline IT89KD-349 & 60.5 & 45 & 28 & 0.37 & 63.5 & 44 & 28.7 & 0.38 \\
\hline IT88D-867-11 & 65.9 & 46 & 28.1 & 0.37 & 67.9 & 45 & 30.0 & 0.33 \\
\hline IT93-734 & 62.5 & 43 & 26.7 & 0.36 & 64.1 & 46 & 31.1 & 0.41 \\
\hline IT93K-273-2-1 & 69.0 & 42 & 31.0 & 0.41 & 71.2 & 43 & 32.4 & 0.43 \\
\hline IT90K-372-1-2 & 89.1 & 43 & 32.0 & 0.43 & 89.7 & 42 & 32.9 & 0.44 \\
\hline Yar Dunga (L) & 90.8 & 68 & 33.1 & 0.44 & 92.8 & 68 & 33.5 & 0.44 \\
\hline $\begin{array}{l}\text { Significance level } \\
(0.05)\end{array}$ & NS & NS & NS & NS & NS & NS & NS & NS \\
\hline SE & 3.69 & 2.05 & 0.58 & 0.0078 & 2.08 & 2.13 & 0.61 & 0.008 \\
\hline
\end{tabular}

NS - Not significant; DFF - Days to $50 \%$ flowering

The grain yield potential of cowpea is generally low when compared with cereal crops like maize and sorghum even when optimal agronomic practices are fully adopted. Result of this investigation showed that cowpea performed better when grown as a sole crop than when grown in a mixture (Table 4 and 5). The number of pods/plant, pod weight and seed yield were significantly reduced when intercropped with Sorghum. Although there was a general reduction in the yield of cowpea as a result of intercropping, highest grain yield was recorded with varieties IT86D-719, IT88D-867-11, IT90K-
372-1-2, and IT89KD-319 when intercropped with sorghum. This corroborates the findings of Ofori and Stern (1987) who reported a yield depression of cowpea as a result of intercropping, but definitely not in agreement with the findings of Singh and Ahuja (1990) who reported a yield increase as a result of intercropping sorghum with cowpea. The number of seeds/pod and threshing percentage revealed a non-significant effect of intercropping, however there was a decrease in threshing percentage in intercropped cowpea in 1997. This agrees with the finding of Blade and Terao (1993). 
Table 4: Effect of intercropping on yield and yield component of Cowpea varieties in a Cowpea/Sorghum mixture in 1997 at Bauchi 1997

\begin{tabular}{|c|c|c|c|c|c|c|c|c|c|c|}
\hline \multirow{3}{*}{ Treatment } & \multirow{2}{*}{\multicolumn{5}{|c|}{ Sole Cowpea }} & \multirow{2}{*}{\multicolumn{5}{|c|}{ Intercropped Cowpea }} \\
\hline & & & & & & & & & & \\
\hline & $\begin{array}{l}\text { No of } \\
\text { pods/plant }\end{array}$ & $\begin{array}{l}\text { No of } \\
\text { seeds/pod }\end{array}$ & $\begin{array}{l}\text { Pod wt } \\
\text { (kg/ha) }\end{array}$ & $\begin{array}{l}\text { Threshing } \\
\%\end{array}$ & $\begin{array}{l}\text { Seed yield } \\
(\mathrm{kg} / \mathrm{ha})\end{array}$ & $\begin{array}{l}\text { No of } \\
\text { pods/plant }\end{array}$ & $\begin{array}{l}\text { No of } \\
\text { seeds/pod }\end{array}$ & $\begin{array}{l}\text { Pod wt } \\
\text { (kg/ha) }\end{array}$ & $\begin{array}{l}\text { Threshing } \\
\%\end{array}$ & $\begin{array}{l}\text { Seed yield } \\
(\mathrm{kg} / \mathrm{ha})\end{array}$ \\
\hline IT89KD-391 & $30 \mathrm{a}$ & 11 & $1453 b$ & 76 & $1110 \mathrm{~b}$ & $30 a b$ & 11 & $1475 b$ & 75.4 & $1112 \mathrm{~b}$ \\
\hline IT93K-452-1 & $27 \mathrm{a}$ & 11 & $980 \mathrm{a}$ & 75 & $739 a$ & $26 a$ & 9 & $1130 \mathrm{a}$ & 69 & $780 \mathrm{a}$ \\
\hline IT90K-277-2 & $36 b$ & 11 & $1269 b$ & 76 & $964 b$ & $38 b$ & 10 & $1507 b$ & 65.7 & $990 b$ \\
\hline IT86D-719 & $30 \mathrm{a}$ & 10 & $1384 b$ & 78 & $1091 b$ & $30 \mathrm{ab}$ & 9 & $1694 b$ & 67.9 & $1150 \mathrm{~b}$ \\
\hline IT89KD-349 & $24 \mathrm{a}$ & 9 & $934 \mathrm{a}$ & 79 & $740 \mathrm{a}$ & $26 a$ & 11 & $1015 \mathrm{a}$ & 67 & $680 \mathrm{a}$ \\
\hline IT88D-867-11 & $38 b$ & 12 & $1450 \mathrm{~b}$ & 74 & $1080 \mathrm{~b}$ & $38 b$ & 11 & $1580 \mathrm{~b}$ & 65.6 & $1036 b$ \\
\hline IT93-734 & $37 b$ & 10 & $973 a$ & 74 & $720 \mathrm{a}$ & $36 b$ & 10 & $1200 \mathrm{a}$ & 66.7 & $800 \mathrm{a}$ \\
\hline IT93K-273-2-1 & $24 \mathrm{a}$ & 11 & $960 a$ & 73 & $709 a$ & $23 \mathrm{a}$ & 10 & $980 \mathrm{a}$ & 68.9 & $675 a$ \\
\hline IT90K-372-1-2 & $38 b$ & 11 & $1610 \mathrm{c}$ & 76 & $1224 \mathrm{c}$ & $38 b$ & 9 & $1804 b$ & 69.3 & $1250 \mathrm{c}$ \\
\hline Yar Dunga (L) & $18 \mathrm{a}$ & 8 & $880 \mathrm{a}$ & 65 & $578 \mathrm{a}$ & $16 a$ & 8 & $1054 \mathrm{a}$ & 58.8 & $620 a$ \\
\hline Sgn level (0.05) & & NS & & NS & & & NS & & NS & \\
\hline SE & 4.40 & 0.37 & 172.0 & & 140.8 & 2.37 & 0.33 & 192.4 & 2.62 & 142.6 \\
\hline
\end{tabular}

Means followed by the same letters are not significantly different at 5\% level of significance according to the Duncan Multiple Range Test (DMRT). N S - Not significant

Table 5: Effect of intercropping on yield and yield component of Cowpea varieties in a Cowpea/Sorghum mixture in 1998 at Bauchi

\begin{tabular}{|c|c|c|c|c|c|c|c|c|c|c|}
\hline \multirow{3}{*}{ Treatment } & \multicolumn{10}{|c|}{1998} \\
\hline & \multicolumn{5}{|c|}{ Sole Cowpea } & \multicolumn{5}{|c|}{ Intercropped Cowpea } \\
\hline & $\begin{array}{l}\text { No of } \\
\text { pods/plant }\end{array}$ & $\begin{array}{l}\text { No of } \\
\text { seeds/pod }\end{array}$ & $\begin{array}{l}\text { Pod wt } \\
(\mathrm{kg} / \mathrm{ha})\end{array}$ & $\begin{array}{l}\text { Threshing } \\
\%\end{array}$ & $\begin{array}{l}\text { Seed } \\
\text { yield }(\mathrm{kg} / \mathrm{ha})\end{array}$ & $\begin{array}{l}\text { No of } \\
\text { pods/plant }\end{array}$ & $\begin{array}{l}\text { No of } \\
\text { seeds/pod }\end{array}$ & $\begin{array}{l}\text { Pod wt } \\
(\mathrm{kg} / \mathrm{ha})\end{array}$ & $\begin{array}{l}\text { Threshing } \\
\%\end{array}$ & $\begin{array}{l}\text { Seed } \\
\text { yield }(\mathrm{kg} / \mathrm{ha})\end{array}$ \\
\hline IT89KD-391 & $33 b$ & 13 & $1730 \mathrm{~b}$ & 78 & $1365 b$ & $33 b$ & 13 & $1570 \mathrm{c}$ & 78.2 & $1228 b$ \\
\hline IT93K-452-1 & $34 b$ & 14 & $1308 \mathrm{a}$ & 79 & $1045 a$ & $34 b$ & 12 & $1240 \mathrm{~b}$ & 78.5 & $973 a$ \\
\hline IT90K-277-2 & $41 \mathrm{c}$ & 13 & $1720 b$ & 78 & $1350 \mathrm{~b}$ & $38 b$ & 11 & $1670 \mathrm{c}$ & 77.8 & $1299 b$ \\
\hline IT86D-719 & $39 b$ & 14 & $2280 \mathrm{c}$ & 76 & $1753 b$ & $36 b$ & 12 & $1658 \mathrm{c}$ & 74.9 & $1242 b$ \\
\hline IT89KD-349 & $36 b$ & 13 & $1640 \mathrm{a}$ & 77 & $1276 b$ & $38 b c$ & 13 & $1102 c$ & 76.2 & $840 \mathrm{a}$ \\
\hline IT88D-867-11 & $38 b$ & 12 & $2584 \mathrm{c}$ & 77 & $1990 \mathrm{bc}$ & $42 \mathrm{bc}$ & 14 & $2386 \mathrm{~d}$ & 70.8 & $1689 \mathrm{c}$ \\
\hline IT93-734 & $40 b$ & 13 & $1520 \mathrm{a}$ & 78 & $1198 \mathrm{a}$ & $40 \mathrm{bc}$ & 10 & $1000 \mathrm{a}$ & 79.8 & $798 \mathrm{a}$ \\
\hline IT93K-273-2-1 & $38 b$ & 13 & $1420 \mathrm{a}$ & 79 & $1127 \mathrm{a}$ & $38 b c$ & 12 & $1246 b$ & 75.4 & $940 \mathrm{a}$ \\
\hline IT90K-372-1-2 & $43 c$ & 12 & $2540 \mathrm{c}$ & 79 & $2019 c$ & $43 c$ & 11 & $2160 c$ & 80.2 & $1732 \mathrm{c}$ \\
\hline Yar Dunga (L) & $21 \mathrm{a}$ & 10 & $1188 \mathrm{a}$ & 62 & $747 a$ & $26 a$ & 10 & $890 a$ & 60.5 & $538 \mathrm{a}$ \\
\hline Sign level (0.05) & & NS & & NS & & & NS & & NS & \\
\hline SE & 3.92 & 0.37 & 317.6 & 1.6 & 261.8 & 1.56 & 0.42 & 312.0 & 2.72 & 243.2 \\
\hline
\end{tabular}

Means followed by the same letters are not significantly different at 5\% level of significance according to the Duncan Multiple Range Test (DMRT). N S - Not significant 
The result of the investigation on sorghum yield and yield component revealed a significant effect of intercropping with cowpea varieties on the head weight of sorghum. In 1997 cropping season, a significant improvement in sorghum head weight was observed when compared with the sole with the exception of varieties IT89KD-349 and IT93K-273-2-1 which gave a lower head weight of $1340 \mathrm{~kg} / \mathrm{ha}$ and $1250 \mathrm{~kg} /$ ha respectively (Table 6). Varieties IT89KD-391, IT90K-277-2 and IT90K-3721-2 recorded higher head weight of $1750 \mathrm{~kg} / \mathrm{ha}, \quad 1740 \mathrm{~kg} / \mathrm{ha}$ and $1880 \mathrm{~kg} / \mathrm{ha}$ respectively. This result agrees with the findings of Pal et al., (1993) who reported yield advantages of legume-cereal intercropping over sole cropping. In 1998, highest head weight was recorded for sorghum when intercropped with varieties IT90K-277-2 (1791kg/ha) and IT90K-372-1$2(1750 \mathrm{~kg} / \mathrm{ha})$ when compared to sole sorghum head weight (1625kg/ha) (Table 6). This recorded increment in this finding agrees with Wanki et al., 1982 and Pal et al., 1993 who had reported yield advantages of legume-cereal intercropping system over sole cropping. However, a significant reduction in head weight was recorded for sorghum when intercropped with varieties IT93K-273-2-1 (1166kg/ha), IT89KD-349 (1250kg/ha) and IT89KD-391 (1375kg/ha). This also corroborates the findings of Balasubramanian et al., 1986 who reported a depression in the yield of sorghum when intercropped with cowpea.

Threshing percentage and 1000-grain weight of sorghum were non-significant. However 1000-grain weight was increased with intercropping in 1998 cropping season (Table 6). This agrees with the findings of Singh (1981) who reported that the total grain weight per plant and 1000 grain weight of sorghum were improved by legume intercrop. The effect of intercropping on sorghum stover yield in 1997 and 1998 was significant. In 1997, the highest stover yield for sorghum was recorded with varieties IT90K-372-1-2 and IT90K-277-2, IT93K452-1 with corresponding yield values of $4150 \mathrm{~kg} / \mathrm{ha}, 3880 \mathrm{~kg} / \mathrm{ha}$, and $3620 \mathrm{~kg} / \mathrm{ha}$, while intercropping with variety IT89KD-349 and IT89KD-391 significantly reduced sorghum stover yield (table 7). In 1998, intercropping with varieties IT90K-372-1-2 and IT88D$867-11$ gave the highest sorghum stover yield of $4570 \mathrm{~kg} / \mathrm{ha}$ and $4400 \mathrm{~kg} / \mathrm{ha}$ when compared to the sole sorghum stover yield of $4250 \mathrm{~kg} / \mathrm{ha}$. Even though varieties IT90K277-2, IT93K-273-2-1, IT86D-719, and IT93K-452-1 gave an equally higher stover yield corresponding to $4179 \mathrm{~kg} / \mathrm{ha}$, $4120 \mathrm{~kg} / \mathrm{ha}, \quad 3990 \mathrm{~kg} / \mathrm{ha}$ and $3950 \mathrm{~kg} / \mathrm{ha}$ respectively. This result also agrees with Chandrashekhar et al., 1986 who reported an increased fodder and dry matter production and an increased leaf area index due to intercropping legume with cereals. The grain yield of sorghum was also significantly affected by intercropping in 1997; most of the varieties intercropped with sorghum gave a higher sorghum yield when compared to the sole crop yield (table 7). The increased yield of sorghum when intercropped with some cowpea varieties confirms the findings of Singh and Ahuja (1990) who reported increased in yield of sorghum as a result of intercropping with cowpea and also in agreement with Pal et al. (1993), who had reported a yield advantage of intercropping over sole cropping. In 1998 the grain yield of sorghum was significantly reduced when grown in intercrop with some cowpea varieties compared to 1997 cropping season.

The, highest grain yield was obtained with varieties IT90K-277-2 (1467kg/ha) and IT90K-372-1-2 (1372kg/ha). Although sorghum grain yield was significantly reduced in 1998 cropping season, the land equivalent ratio shows an advantage of 
Evaluating Yield Performance of Cowpea Varieties................IBRAHIM et al.

intercrops over the sole crop in both cropping season. This agrees with the findings of Burton et al. (1983). The values of land equivalent ratio recorded were greater than 1.00 with sorghum intercrop, which implies an advantage over sole cropping, this further corroborates the findings of Pal et al. (1993).
Yield in 1998 was highest for all the treatments compared to 1997 and could be due to climatic variation, especially rainfall experienced during the two year period of the investigation.

Table 6: Effect of intercropping cowpea varieties on yield components of sorghum in1997 and 1998 at Bauchi

\begin{tabular}{|c|c|c|c|c|c|c|}
\hline \multirow[b]{3}{*}{ Treatment } & \multicolumn{6}{|c|}{ Sorghum } \\
\hline & \multicolumn{3}{|c|}{1997} & \multicolumn{3}{|c|}{1998} \\
\hline & $\begin{array}{l}\text { Head } \\
\text { wt(kg/ha) }\end{array}$ & Threshing(\%) & $\begin{array}{l}\text { 1000-grain } \\
w t(g)\end{array}$ & $\begin{array}{l}\text { Head } \\
\text { wt(kg/ha) }\end{array}$ & $\begin{array}{l}\text { Threshing } \\
(\%)\end{array}$ & $\begin{array}{l}\text { 1000-grain } \\
\text { wt }(\mathrm{g})\end{array}$ \\
\hline Sole & 1500 & 78 & 29.9 & 1625 & 77 & 39.9 \\
\hline IT89KD-391 & $1750 \mathrm{~b}$ & 78 & 28.7 & $1375 \mathrm{a}$ & 79 & 38.7 \\
\hline IT93K-452-1 & $1580 \mathrm{a}$ & 78 & 28.1 & $1541 \mathrm{~b}$ & 75 & 38.0 \\
\hline IT90K-277-2 & $1740 \mathrm{~b}$ & 77 & 29.2 & $1791 \mathrm{c}$ & 81 & 39.2 \\
\hline IT86D-719 & $1520 \mathrm{a}$ & 77 & 28.9 & $1458 b$ & 79 & 38.9 \\
\hline IT89KD-349 & $1340 \mathrm{a}$ & 78 & 28.2 & $1250 \mathrm{a}$ & 79 & 38.2 \\
\hline IT88D-867-11 & $1600 \mathrm{~b}$ & 76 & 28.8 & $1583 b$ & 78 & 38.7 \\
\hline IT93-734 & $1550 \mathrm{a}$ & 77 & 29.0 & $1500 \mathrm{~b}$ & 77 & 39.0 \\
\hline IT93K-273-2-1 & $1250 \mathrm{a}$ & 79 & 29.9 & $1166 a$ & 77 & 38.9 \\
\hline IT90K-372-1-2 & $1880 \mathrm{~b}$ & 79 & 29.4 & $1750 \mathrm{c}$ & 78 & 38.4 \\
\hline Yar Dunga (L) & $1580 \mathrm{a}$ & 76 & 27.9 & $1420 \mathrm{~b}$ & 76 & 37.9 \\
\hline $\begin{array}{l}\text { Level of } \\
\text { significance }(0.05)\end{array}$ & & NS & NS & & $\mathrm{NS}$ & NS \\
\hline SE & 118.4 & 0.33 & 0.2 & 124.8 & 0.58 & 0.14 \\
\hline
\end{tabular}

Means followed by the same letters are not significantly different at 5\% level of significance according to the Duncan Multiple Range Test (DMRT).; N S - Not significant

Table 7: Effect of intercropping cowpea varieties on the yield of maize and LER in 1997 and 1998

\begin{tabular}{|c|c|c|c|c|c|c|}
\hline \multirow[b]{3}{*}{ Treatment } & \multicolumn{6}{|c|}{ Sorghum } \\
\hline & \multicolumn{3}{|c|}{1997} & \multicolumn{3}{|c|}{1998} \\
\hline & $\begin{array}{l}\text { Stover } \\
\text { yield(kg/ha) }\end{array}$ & $\begin{array}{l}\text { Grain } \\
\text { yield(kg/ha) }\end{array}$ & LER & $\begin{array}{l}\text { Stover } \\
\text { yield(kg/ha) }\end{array}$ & $\begin{array}{l}\text { Grain } \\
\text { yield(kg/ha) }\end{array}$ & LER \\
\hline Sole & 3458 & 1176 & - & 4250 & 1253 & - \\
\hline IT89KD-391 & $3050 \mathrm{a}$ & $1365 b c$ & 1.93 & $3490 b$ & $1092 \mathrm{a}$ & 1.72 \\
\hline IT93K-452-1 & $3620 b$ & $1247 b$ & 2.11 & $3950 b$ & $1159 a$ & 1.89 \\
\hline IT90K-277-2 & $3880 b$ & $1345 b c$ & 2.17 & $4179 c$ & $1467 b$ & 2.13 \\
\hline IT86D-719 & $3650 \mathrm{~b}$ & $1170 \mathrm{a}$ & 2.04 & $3990 b$ & $1156 a$ & 1.63 \\
\hline IT89KD-349 & $3000 \mathrm{a}$ & $1056 a$ & 1.77 & $3100 \mathrm{a}$ & $988 \mathrm{a}$ & 1.39 \\
\hline IT88D-867-11 & $3250 \mathrm{a}$ & $1230 \mathrm{~b}$ & 2.00 & $4400 \mathrm{c}$ & $1238 b$ & 1.83 \\
\hline IT93-734 & $3150 \mathrm{a}$ & $1194 a$ & 2.13 & $3630 \mathrm{~b}$ & $1157 \mathrm{a}$ & 1.59 \\
\hline IT93K-273-2-1 & $3600 \mathrm{~b}$ & $987 \mathrm{a}$ & 2.05 & $4120 c$ & $902 \mathrm{a}$ & 1.55 \\
\hline IT90K-372-1-2 & $4150 \mathrm{c}$ & $1493 c$ & 2.29 & $4570 \mathrm{c}$ & $1372 b$ & 1.95 \\
\hline Yar Dunga (L) & $3400 b$ & $1207 b$ & 1.84 & $3550 \mathrm{a}$ & $1088 \mathrm{a}$ & 1.57 \\
\hline SE & 236.2 & 139.8 & - & 429.2 & 105.6 & - \\
\hline
\end{tabular}

Means followed by the same letters are not significantly different at 5\% level of significance according to the Duncan Multiple Range Test (DMRT); N S - Not significant 


\section{Conclusion and Recommendation}

Cowpea growth parameters were not significantly affected by intercropping in both 1997 and 1998. Number of pods/plant, pod weight and seed yield of cowpea were significantly reduced when intercropped with sorghum. For sorghum intercropping with cowpea varieties was significant in affecting the growth parameters, head weight, stover and grain yield. Land equivalent ratio greater than 1 and a maximum of 2.29 were recorded in the two years of the investigation.

Based on the result of the two year field investigation, it may therefore be suggested that for intercropping purposes, cowpea varieties IT90K-372-1-2, IT90K-277-2, IT88D-867-11, IT89KD-391 and IT86D-719 are more suitable with sorghum for high yield in Bauchi environment. However research is needed on nitrogen fixation and factors influencing N-transfer between the crops.

\section{References}

Agboola A. A. and Fayemi, A. A. (1971). Preliminary trials on the intercropping of maize with different tropical legumes .Journal of Agricultural Science 77. 219- 225

Blade, S. F. and Terao, T (1993).Summaries of review papers 35 - 40. Crop improvement division, IITA, Ibadan, Nigeria.

Burton, J. W., Brim, C. A. and Rawlings, J. O. (1983). Performance of nonnodulating and nodulating soybean isolines in mix-culture with nodulating cultivars. Crop Science. 23: $469-473$.

COMBS (Collaborative group on maize based systems Research (1993). Improvement of soil fertility and weed suppression through legume-based technologies, IITA Research guide 48. Ibadan, Nigeria: training program,
International Institute for Tropical Agriculture (IITA).

Desir, S. and Pinchinat, A. M. (1976). Turialla 26:237 - 240. (Francis, C. A. Flor, C. A. and Prager, M (1978c)). Effects of bean association on yields and yield component of maize. Crop science 18(1): 760 - 764 .

Elemo, K. A. and Olufajo, O. O. (1991). Agronomic testing of improve varieties in maize-cowpea mixed cropping system. Cropping scheme meeting. Report on farming system research programme. $25^{\text {th }}$ February $-1^{\text {st }}$ March, 1991.

Enyi, B. A. C. (1973). Effect of intercropping maize or sorghum with cowpea, pigeon peas or beans. Experimental Agriculture, 9: 83 - 90.

Goodman, P J. and Collinson, M. (1986). Effect of three clover varieties on growth, $15 \mathrm{~N}-\quad$ uptake fixation by rye grass/white clover mixtures at 3 sites in wales. Grass forage science, 41: $191-198$.

Nnadi, L. A. (1980). Effect of grain legumes and sorghum on soil nitrogen status and the yield of subsequent maize crop. Samaru Journal of Agricultural Research, 1:183 - 190

Ofori, F. and Stern, W. R. (1987). Cereallegume intercropping systems. Advances in Agronomy, 41: 41 90.

Pal, U. R.; Oseni, T. O. and Norman, J. C. (1993). Effect of component densities on the productivity of soybean/sorghum intercrop. Journal of agronomy and Crop Science. 170: $66-70$.

Singh, R. S. P. (1981). Studies on spatial arrangement in sorghum-legume intercropping system. Journal of Agricultural Science, Cambridge, 97: $655-661$. 
Evaluating Yield Performance of Cowpea Varieties.................IBRAHIM et al.

Singh, S. P. and Ahuja, K. N. (1990). Intercropping grain sorghum with fodder legume

Wanki, S. B.; Fawusi, M. O. A. and Nangju, U. (1982). Pod and grain yields from intercropping maize and Vigna unguiculata(L) Walp in Nigeria. Journal of Agricultural Science, Cambridge. 99: 13 - 17.
Webber, G.; Smith, J. and Manyong, V. (1996). Systems dynamics and the

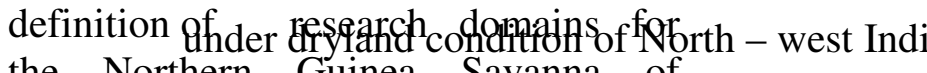
the Northern Guinea Savanna of W/Africa. Agriculture, ecosystems and environment, 57: 133 - 148.

Wiley, R. W. (1979) Intercropping - its importance and research needs. Parts 1 and 2. Field Crop Abstracts, 32: 1 85. 